Hesselink, I. John ${ }^{1}$

\title{
Law and Gospel or Gospel and Law? Karl Barth, Martin Luther and John Calvin
}

\begin{abstract}
For Calvin the order of the law-gospel relation may be put this way: Law of creation (natural law) - revealed law (the law of Moses) - the gospel - the gracious law (third use) as a norm and guide for believers. The same outline would follow for Luther except that the third or positive use of the law plays a minor role in his thinking. On the surface Barth would seem to have more affinity with Calvin but the differences are significant because of Barth's rejection of any notion of the antithesis of law and gospel and his subsuming the law in all its functions under God's grace.
\end{abstract}

\section{INTRODUCTION}

Karl Adam, a German Roman Catholic theologian, is reported to have said that Karl Barth's Commentary on Romans "dropped like a bomb on the playground of theologians." ${ }^{2}$ It immediately established Karl Barth, then a pastor in a small Swiss village, as a theological force to be reckoned with. It was a striking challenge to the German liberal theological establishment of the first half of the twentieth century from which it never completely recovered.

Not long afterwards Barth published a little monograph entitled Evangelium und Gesetz (Gospel and Law) in 1935 in the journal Theologische Existence heute, No. XXXII. ${ }^{3}$ Barth had planned to give this as a lecture in Barmen that year but was prevented from giving it by the Gestapo. As he was being escorted across the border to Switzerland by the German police, someone else read the lecture in his place. ${ }^{4}$ This little treatise did not evoke much of a response in either the liberal theological world nor the evangelical world in Britain or the United States, but it was regarded as a frontal attack on a key Lutheran doctrine by the Lutheran establishment. For in Lutheranism the only doctrine that has higher priority than the Law-Gospel schema is the doctrine of justification. Whereas conservative Reformed and evangelical scholars were principally concerned with Barth's doctrine of revelation, many Lutheran theologians found this reversal of the law and gospel approach to be a serious flaw, if not a heresy, in Barth's theology. ${ }^{5}$

Eventually there were responses and more moderate critiques by theologians from other traditions. Several of the standard treatments of Barth's theology have been less polemical in their treatment of this subject in Barth's theology. ${ }^{6}$ Two of the earlier and more penetrating analyses were by the Dutch Reformed theologians Hendrikus Berkhof and G. C. Berkouwer. ${ }^{7}$ In recent years, however, this topic has not attracted much attention. ${ }^{8}$ Nevertheless, quite apart from the dispute caused by Barth's reversal of the law-gospel order, the question of the role of the law in the Christian life, in particular Calvin's emphasis on the third use of the law (usus legis tertius) -the law as a norm and guide for the Christian life - continues to be of relevance both for soteriology and Christian ethics. The situation ethics movement may have run its course, but Christian theology and the church will always be challenged by the question of the nature of the law and the gospel, however one conceives of their relationship. 
At the outset it must be noted that Barth's reversal of the law-gospel order is not simply a rejection of the traditional ordering of these topics. Nor is it a modified version of the Reformed stress on the third use of the law as some Lutherans have suggested. Rather, a careful scrutiny of Barth's use of these terms reveals a radically new understanding of both the law and the gospel. Despite the fact that Barth does not devote a section to this subject in his Church Dogmatics, he deals with it again in various contexts: in his prolegomena (CD.I, 2), in his doctrine of God (CD.II, 2), his ethics (CD.III, 2) and his doctrine of reconciliation (CD.IV, 1 and CD.IV, 3). ${ }^{9}$ Granted, there is no extended discussion of this theme in these volumes, with the exception of IV, 3 where Barth takes on his Lutheran critics. Nevertheless, even where this subject is not explicitly discussed, it is central to understanding Barth's whole theology. A brief summary of his monograph Gospel and Law will show why.

Barth begins by conceding that "the traditional order, 'Law and Gospel,' has a perfect right in its place, "but he quickly adds, "Anyone who wishes to approach our subject must speak first of the Gospel."10 Barth bases this approach on passages like Galatians 3:17 where the Apostle Paul points out that the law followed the promise. Moreover, the law is fulfilled in the promise. Hence, "the law would not be the law if it were not hidden and enclosed in the ark of the covenant. And the gospel, too, is only the gospel if the law - that which 'came in between' (Romans 5:20) - is hidden and enclosed in it as in the ark of the covenant." 11 Then follows the thesis of this treatise.

The gospel is not the law, just as the law is not the gospel, but because the law is in the gospel, comes from the gospel, and points to the gospel, we must first of all know the gospel in order to know about the law and not vice versa. ${ }^{12}$

At first glance it may seem as if Barth is saying what is obvious: the law and the gospel are interrelated but are not the same. This is affirmed again in a later context: "We would contradict the whole of Holy Scripture if we were unwilling to distinguish between the two." At the same time, Barth adds, "We would also contradict the whole of Holy Scripture if we wished to separate the two." ${ }^{13}$ Moreover, both Luther and Calvin taught that the law serves the gospel by making us aware of sin and thereby leading us to seek grace and forgiveness, the so-called usus elenchticus (for Luther the second and primary function of the law, for Calvin the first of three uses or functions). However, neither Luther nor Calvin ever speaks of the law being in the gospel. That this is more than merely a terminological difference is seen in the following sentence which is the most frequently quoted statement from his monograph, Gospel and Law, viz., "The law is nothing else than the necessary form of the Gospel whose content is grace." Or, as he puts it in his Church Dogmatics, the one Word of God "in its content is gospel; in its form and fashion it is law." ${ }^{14}$ It is particularly this claim that has evoked the antipathy of so many Lutheran theologians, as well as raised questions among Reformed and other theologians.

First, one must understand what Barth means by describing the law as the form of the gospel. Does this mean a virtual amalgamation or synthesizing of the two? Hardly, for Barth goes on to say that "the differentiation between content and form also designates an infinite distinction." 15 Unfortunately, in this context Barth only says what this distinction does not mean. Here I agree with Gerhard Ebeling that "this formula is, quite apart from its theological intention, unclear from the point of logic. ...The concept of 'form,' so overloaded in view of the history of philosophy remains unclear." 16

Herbert Hartwell, an able and sympathetic interpreter of Barth's theology indirectly answers the question in this way:

The gospel, i.e., God's grace in Jesus Christ, manifests itself as God's gracious claim on man, on his obedience. ...The grace of God in Jesus Christ is therefore also a demanding and 
commanding grace, calling man, as Jesus Christ's disciple and witness to the active service of God and his fellow-men. This is why this grace, and therefore the gospel is said to have the form of the law. The latter is the instrument whereby, and the form in which, God's grace in Jesus Christ accomplishes its purpose. ${ }^{17}$

In short, the law is the form of the gospel in that "it bears witness to the grace of God."18 Here we see the Christ centric nature of Barth's ethics which at the same time is grounded in Barth's doctrine of election. The law, for Barth, no longer has an accusing function. It does command but only as the law of the gospel, the law included in the gospel. And the gospel is summed up in Jesus Christ who has fulfilled the law and is the end (telos, not finis) of the law (Rom 10:4). ${ }^{19}$ The Word of God is ultimately not a duality - or two words as some Lutherans put it - but one Word and that Word is grace: "free sovereign grace, God's grace, which therefore can also mean law, which also means judgment, death, and hell, but grace and nothing else."20

"The law is also God's Word, if it is further grace that God's Word is spoken aloud and becomes audible, and if grace means nothing else than Jesus Christ." Thus the will of God "is visible as grace in both form and content." 21 Moreover, the grace of God, even in the form of the law, has already been accomplished for us by Jesus Christ in his once-for-all intercessory work on our behalf. "He intercedes for us, however, by believing in our place - it took the eternal Word incarnate to do that - and that means by saying 'yes' to God's glory and thus to man's misery" (emphasis mine). ${ }^{22}$ Consequently, in the gracious work of the law there is "a prior decision concerning man's self-determination. It is the claiming of his freedom." ${ }^{23}$ Thus the law of God "requires from us nothing more or less than that we should be what we are, namely, men elected and saved by Jesus Christ." 24

It should be clear that Barth's reversal of the law-gospel approach has profound implications. It is not simply a terminological change. For, according to Barth,

The law is a summons to participate in the gospel. But it is not the sort of summons

that is usually accorded the law in Protestant orthodoxy, viz., to convict of sin as a prior

preparation for the gospel... Its true function is to call men to realize their true being which

they have already in Jesus Christ. ${ }^{25}$

Quite apart from Barth's view of election, which differs fundamentally from that of Luther and Calvin, we see here also another significant difference, viz., in regard to the accusing function of the law. Barth does not seem to take seriously this use of the law which in Romans and Galatians is so prominent (see Rom 3:19-20; 7:7-11; 8:2; Gal 3:19, 24-5. Cf. 2 Cor 3:6-11) and for Luther was the principal use of the law. Barth, of course, is aware of these negative references to the law, but he gets around them by insisting that such references are a misunderstanding and distortion of the law as graciously given to the people of Israel, the law praised by the psalmist. In his monograph, Gospel and Law, Barth refers again and again to the "misused, desecrated corrupt, and deformed and distorted law." ${ }^{26}$ It is the law, "dishonoured and emptied by sin's deception," which is an instrument of the wrath of God. ${ }^{27}$

That this interpretation does not do justice to Paul's understanding of the law has been noted by several theologians, and not all of them Lutheran. One of the first, as noted above, was Hendrikus Berkhof, the Dutch theologian who in general has been a very sympathetic interpreter of Barth. In a booklet published in 1953 Berkhof complained that preachers in the Netherlands who were influenced by Midden-orthodoxie no longer preached the law, particularly the accusing function of the law. ${ }^{28}$ This, Berkouwer points out, is a result of Barth's viewing the law as "nothing more than the form of the gospel, a conception which has many consequences." 29 Another sympathetic Barth interpreter, and also Reformed, Otto Weber, also points that Barth does not "see clearly" or take "sufficient account of a passage like Galatians 4:4f., and "the fact 
that the law in the old covenant was the unfulfilled law." In short, Barth "demonstrates a static character which does not correspond to the enormous tension and movement of the biblical witness." 30

Lutheran interpreters, on the whole, have been even sharper in their criticisms, although a few have sought rapprochement between Barth and Luther on this issue. ${ }^{31}$ Others have suggested that the real difference is more between Barth and Lutheranism than Barth and Luther, ${ }^{32}$ and that basically Barth "does not reverse the sense" of the Lutheran and Pauline sequence of law and gospel. ${ }^{33}$ I question both of these suggestions, although it is true that in modern day Lutheranism the preaching of law and gospel has often been taught in a dogmatic fashion unlike that of Luther. ${ }^{34}$ Even more erroneous is the claim by Herman Sasse, a German Lutheran theologian of a past generation, that "Barth adheres to the Reformed Church with respect to ... the teaching about the relation of law and gospel." 35 There are more affinities between Barth and Calvin than Barth and Luther because of the more positive view of the law and the Old Testament by Barth and Calvin, but it should already be apparent that the differences are not insignificant.

This brings up a related issue in regard to Barth and Luther in particular, although here again Luther is closer to Calvin than to Barth. That is, Barth's insistence that it is not the proclamation of the law, as such, but the gospel that brings us to a knowledge of our sinfulness. "No law," says Barth, "not even the law of Moses, can judge a man as the New Testament judges him." 36

The Christian concept of sin is not to be gained in a vacuum, remoto Christo, but from the gospel to the extent that the gospel itself, as the good news of man's liberation by and for the free God, has also the character and form of the true law of God, the promise of the grace of God containing his no less gracious claim, as the ark of the Old Testament covenant contained the tables of the Decalogue. In all its forms sin is man's perverted dealing with the stern goodness and righteous mercy of God addressed to him in Jesus Christ. ${ }^{37}$

The gospel - or the law contained in the gospel - not only brings us to an awareness of our sin but also reveals to us the true nature of sin. "God's grace (and thus the law) irrefutably and unambiguously illuminates the fact and meaning of our sinfulness." The depth of our sins "can only be realized when we are confronted with the Christ who died in our place and respond in faith. This also "discloses the nature of sin, against which God contends in Jesus Christ, the forgiveness of which he has prepared for us in him." 38

There is something to be said for this, but it need not be either/or, i.e., either the law makes us aware of our sin or the gospel. One cannot dismiss the clear teaching of the Apostle Paul on this issue, but at the same time it must be conceded that the depth of our sinfulness is revealed above all when we stand before the cross of Christ and sing, "Were you there when they crucified my Lord?" In this regard, the approach of the Heidelberg Catechism may be instructive. In the first part on sin or guilt, Question 3 asks, "How do you come to know your misery?" Answer: "The law of God tells me." Question 4 asks, "What does God's law require of us?" 39 Now comes the surprising answer, for it is not the ten commandments that are cited here but rather Jesus' teaching about the two great commandments. Thus, it is when we are challenged by the love commandments that we come to see the depth of our sin. The ten commandments, however, appear in Part III of the Catechism where the theme is gratitude! This is an illustration of the third use of the law whereby it provides guidance for the redeemed Christian.

In conclusion, it should be quite apparent that Barth's reversal of the law-gospel sequence touches on almost every aspect of his theology. One can only understand the full significance of this issue when his whole theological system is taken into account. Jüngel is therefore probably correct in stating that "Whoever attacks Barth here is going for the jugular." ${ }^{40}$ Barth, in effect, confirms this judgment in one of the very last volumes of his Church Dogmatics. Here he lists five 
areas where he says he "cannot understand the counter-thesis [to his gospel and law proposal], advanced with varying degrees of sharpness and consistency" by various Lutheran authors, ${ }^{41}$ that the gospel and law differ and are even antithetical in significance and function." 42 He prefaces these remarks with the telling statement that his conception of gospel and law, as delineated in various sections of his dogmatics and in Gospel and Law "belongs to the bedrock (eisernen Bestand) of my dogmatics as hitherto presented." 43

\section{MARTIN LUTHER}

Martin Luther can be dealt with more briefly, but not because his understanding of the law is all that simple. For example, it is generally assumed by most Lutherans that Luther did not believe in a third use of the law, thereby separating him from both Calvin and Barth. There is a good basis for this view because in one of his most important works, his commentary on Paul's Letter to the Galatians, he states that there are only two uses of the law. At several points in this commentary he refers to the uses of the law, but only lists two. The first for him is the civic or political use of the law (for Calvin this is the second). This use of the law "is to restrain the wicked." 44

This civic restraint is extremely necessary and was instituted by God, both for the sake of public peace and for the sake of preserving everything, but especially to prevent the course of the gospel from being hindered by the tumults and seditions of wild men. ${ }^{45}$

Calvin uses different terminology to describe this use of the law and they are agreed that this is an important function of the law - but for Calvin not the most important one. For Luther that is the usus elenchticus, "the theological or spiritual use," as he describes it. Not only that, "this is the primary purpose of the Law of Moses, that through it sin might grow and be multiplied, especially in the conscience." Luther finds this use discussed "magnificently" by Paul in Romans 7. ${ }^{46}$ However, whereas Calvin describes the third use of the law as the "principal" and "proper purpose of the law," ${ }^{47}$ Luther says that "the true function (officium) and chief and proper use of the law is to reveal to man his sin, blindness, misery, wickedness, ignorance, hate, and contempt of God..." 48 "It follows, therefore, that the law with its function does contribute to justification - not because it justifies, but because it impels one to the promise of grace and makes it sweet and desirable... This is its true function and use, namely, that it is a most useful servant impelling us to Christ." 49

Nothing is said in his monumental commentary on Galatians about a third use of the law. Moreover, since he stresses so strongly the second use of the law (for Calvin the first), most Lutheran scholars have concluded that Luther does not recognize a continuing positive function of the law for believers. However, when one examines Luther's exposition of the Decalogue, a different picture emerges. As in most of the Reformation and subsequent catechisms, Luther assigns a special place to an exposition of the dialog. Karl Holl, the eminent German Lutheran historian of a past era, concluded that Luther's ethic is not based on any doctrine of virtues or goods but is one of obligation (Pflichtenlehre) whose point of departure is the Decalogue. ${ }^{50}$ Moreover, Gerhard Heintze, in a study of Luther's preaching on law and gospel, concludes that Luther, despite the formal structure of his catechisms, actually treats the Decalogue from the standpoint of faith. That is, the evangelical promise, not the law of nature, is the background against which he interprets the commandments. ${ }^{51}$

Various statements of Luther's could be cited in support of these contentions, but it should suffice to quote his glowing testimonials in his Large Catechism. In the Preface he writes: "Anyone who knows the ten commandments perfectly knows the entire Scriptures... What is the whole Psalter but meditations and exercises based on the first commandment?" He is even more 
eloquent in the conclusion to his exposition of the ten commandments:

Here, then, we have the ten commandments, a summary of divine teachings on what we are to do to make our whole life pleasing to God. They are the true fountain from which all good works must spring, the true channel through which all good works must flow. Apart from these ten commandments no deed, no conduct can be good or pleasing to God, no matter how great or precious it may be in the eyes of the world. ${ }^{52}$

These encomiums of the law may not seem to jibe with what Luther says about the law in other contexts. In the Smalbald Articles, for example, Luther sounds the same note as in his Galatians Commentary. Here again, "the chief function or power of the law is to make original sin manifest and show man to what utter depths his nature has fallen and how corrupt it has become," 53 In the next section of these Articles, "Repentance," Luther makes an important addition: "To this office of the law the New Testament immediately adds the consoling grace of the gospel." However, "where the law exercises its office alone, without the addition of the gospel, there is only death and hell, and man must despair like Saul and Judas." 54

This is what Thomas M. Mc Donough, O.P. in his study of Luther's confessional writings in regard to law and gospel in Luther calls a "split perspective." That is, for the unrepentant sinner the law brings nothing but wrath and judgment, but for the Christian it serves an evangelical purpose because joined with the gospel and its promises, it leads to Christ and salvation. ${ }^{55}$ Here we have simply a law-gospel order, and of a nature quite different from Karl Barth.

However, in his treatment of the Decalogue and elsewhere ${ }^{56}$ Luther approaches a third use of the law as taught by Melanchthon, the Formula of Concord, and Calvin. Interpretations of Luther vary considerably in this regard - even by Lutherans - but I think Mc Donough (a Roman Catholic) is correct when he writes concerning Luther's exposition of the ten commandments in the large Catechism.

For the man of faith, the fulfilment of the law, and all that belongs to it in the way of rewards and blessings, follows as a kind of effect of the believer's inner act of faith and passive justification... In this sense the just man, the one made righteous by the 'power of God's Word,' is bound to observe the law as a living tree is bound to bring forth good fruit; his observance of the commandments, his good deeds, flow from the heart as a matter of course, freely and naturally, not as a result of violence or constraint. ${ }^{57}$

The well-known German Lutheran theologian/ethicist Helmut Thielicke has a chapter in his Theological Ethics on "The Continuing Pedagogic Significance of the Law for Believers" in which he posits that for Luther the law is not only "a loving reminder" for the justified believer but also - in Luther's words - must "be retained in order that the saints may know what works God requires for the exercise of obedience to him." 58 Hence he sees in Luther something approaching a third use of the law, although in contrast to Calvin it "plays only a very secondary role in Luther's thought." 59

One other dimension of Luther's concept of the law needs to be noted, for here too, there is a fundamental difference with Barth and a basic agreement with Calvin, viz., the notion of natural law or the law of nature. ${ }^{60}$ Both reformers believed that even in fallen humanity there was some sense of right and wrong. This is based primarily on Romans 2:14-15, which speaks of the law written on the hearts of the Gentiles. ${ }^{61}$ This law is engraved by God on the hearts and consciences of all human beings. Calvin, like Luther, sees the ten commandments as having the same formal content as that of the law of nature implanted in the consciences of those outside the covenant community. But Calvin appeals to this continuity less frequently than Luther. In his introduction to the discussion of the ten commandments in the Institutes Calvin makes a positive reference and then quickly hedges it with limitations. He begins by saying, "Now that inward 
law which we have above described as written, even engraved upon the hearts of all, in a sense asserts the very same things that are to be learned from the two Tables." 62 One may ask, "the very same things?" If so, why the law of Moses? However, Calvin quickly allays such concerns.

But man is so shrouded in the darkness of errors that he hardly begins to grasp through this natural law what worship is acceptable to God. Surely he is very far removed from a true estimate of it... Accordingly (because it is necessary both for our dullness and for our arrogance), the Lord has provided us with a written law to give us a clearer witness of what was too obscure in the natural law... ${ }^{63}$

Hence the need for revealed law, the ten commandments in particular. The conscience and the concomitant sense of justice and equity play an important role in Calvin's thinking, ${ }^{64}$ but they give no grounds for a natural theology or an optimistic view of the human condition. Calvin puts any such notions to rest with the terse statement, "The end of natural law is that man may be rendered inexcusable" (ut reddatur homo inexcusabilis). ${ }^{65}$

Luther's view is basically the same but the accent falls on the continuity of natural law and revealed law, particularly the law of nature and the ten commandments. In particular, Luther emphasizes that Christ's law of love is inscribed by nature in the hearts of all people. "For nature, like love, teaches that I should do as I would be done by (Mt 7:12)." In this same treatise Luther again correlates the two as he spells out what this implies. "When you ignore love and natural law, you will never succeed in pleasing God..." (emphasis mine). ${ }^{66}$ Thus the essence of the law is contained in the Golden Rule. One does not find similar statements in Calvin.

However, where the two reformers take an identical position is in their interpretation of Romans $2: 14-15$ and in the contention that what we have here in the ten commandments is both a reaffirmation and clarification of natural law. Luther writes, for example, that

God wishes the law to be taught and he reveals it divinely, nay he inscribes it on the hearts of all men, as Paul proves in Romans 2. And from just this natural knowledge all the books of the sounder philosophers have been born, of Aesop, Aristotle, Plato, Xenophon, Cicero, Cato. $^{67}$

Here, too, however, Luther goes beyond Calvin in asserting that Moses was not the author but only the interpreter of various natural laws. He concedes that because of sin our natural knowledge of the law of God is weak and obscure, but he still makes bold statements unlike anything found in Calvin.

It was not Moses that was the author of the Decalogue, but from the foundation of the world the Decalogue has been inscribed on the hearts of all men... For there has never been any nation under the sun so brutal or barbarous and inhuman as not to be aware (quin senserit) that God is to be worshipped and loved. ${ }^{68}$

Again, with typical hyperbole, he writes, "It is certain that the law might be preached a hundred years in vain, as to some ass, if it were not written on our hearts so that when we are admonished we instantly say: 'Yes, that is so." 69 But sometimes hyperbole turns into extravagant statements that contradict views expressed in another context. Recall, for example, how he praised the ten commandments in his Large Catechism. But in a sermon, "How Christians Should Regard Moses," a very different note is sounded. Luther here is apparently reacting against the Enthusiasts' (Schwärmer) who believed that in the law of Moses there could be found a detailed model for society. This may help explain Luther's diatribe, but it is still extreme. The law of Moses, he says, was given to the people of Israel and hence has no binding power on Gentiles or Christians. Moses and his commandments are to be followed only insofar as his teachings agree with the New Testament and natural law. There is some truth in this but then Luther seems to throw the baby out with the bath water. 
Moses is dead. His rule ended when Christ came. He is of no further service... If I accept Moses in one respect (Paul tells the Galatians in chapter 5 [:3], then I am obligated to keep the entire law. For not one little period in Moses pertains to us. ${ }^{70}$ "Therefore, tell this to Moses: Leave Moses and his people together; they have had their day and do not pertain to me." 71 That, on the one hand, but in this same sermon Luther says on the other hand, "I want to keep Moses and not sweep him under the rug, because I find three things in Moses." They turn out to be: (1) a model for present day rulers; (2) "the promises and pledges of God about Christ"; and (3) "the beautiful example of faith, love, and the cross as shown in the fathers: Adam, Abel, Noah, Abraham, Isaac, Jacob, Moses, and all the rest." ${ }^{\prime 2}$ (Luther seems to overlook the fact that these are all flawed characters.)

What are we to make of all of this? ${ }^{73}$ Despite the complexity and seeming contradictions in some of the above statements, one thing is clear. The commandments, whether the ten commandments or other commandments in the Mosaic corpus, are not binding on us except, and only insofar as, they reflect the law of nature and the teaching of Christ. And thus their function is basically negative. Luther may teach a third use of the law but it is definitely a minor motif.

\section{CALVIN}

When we come to Calvin, the question of law and gospel is less complicated than with either Luther or Barth. He lays out his position in clear and systematic fashion in the Institutes, Book II, chapter 7. In the following chapter he has a detailed exposition of the ten commandments and in chapters 10 and 11 he discusses the similarities and differences between the Old and New Testaments.

Nevertheless, Calvin is often misunderstood and caricatured as a legalist and Lawgiver (Gesetzgeber) who knows little of the love and grace of God as found in Luther, not to mention Karl Barth. Reinhold Seeberg, for example, in his Dogmengeschichte declares that "a consequence of Calvin's legalism is that he tends to blur the boundaries between the Old and New Testaments." 74 Here we find repeated references to "the legal (gesetzlich) tendency which is maintained in Calvin's doctrine of Scripture." 75 Similarly, the German church historian, Hans von Schubert, avers that "the equation of the Old Testament with the New gives to Calvin's biblistic moralism the severe characteristic of Old Testament legality (Gesetzlichkeit)."76 Finally, the Old Testament scholar, Emil Kraeling (also a Lutheran), claims that "Calvin really abandons Paul's (and Luther's antitheses of law and gospel." 77

Here I can only try to demonstrate that Calvin recognizes as sharp an antithesis between law and gospel as Luther, despite his emphasis on the fundamental unity of the various covenants.

One of the problems in dealing with this issue is the failure of Calvin's critics to note Calvin's careful distinction between the various meanings of law. For it can stand for the Old Testament as a whole, the old covenant in contrast to the new, the whole of the Mosaic legislation as found in the Pentateuch, the ten commandments, or the law as sometimes depicted by Paul in terms of judgment and a curse because of $\sin$.

In any case, for Calvin, as for Luther, there is not only a difference between the law and the gospel but even an antithesis insofar as the law is opposed to the gospel. Thus, for example, when the Apostle Paul in Galatians 3:19 opposes the law given to Moses to the promise given to Abraham, Calvin observes that the law here is separated from the promises of grace and is being considered only in view of its "peculiar office, power, and end." ${ }^{78}$ This law, the law which is the antithesis of the gospel, is the narrow, peculiar sense of the law, the "bare law" (nuda lex). ${ }^{79}$ The 
law, so conceived, is separated from its original context, the covenant; it is a bare letter without the Spirit of Christ. It has nothing but rigorous demands which place all humanity under the curse and wrath of God. ${ }^{80}$ Concerning the law, so understood, Calvin is no less compromising than Luther in opposing the law to the gospel. Everything depends on what is meant by "law."

The relation between law and gospel, therefore, is not simply a twofold distinction between form and substance, but a threefold distinction:

1. A unity of the substance of the doctrine.

2. A distinction in the form or mode of instruction (forma docendi).

3. An antithesis of letter and Spirit.

\section{Unity of substance}

It is impossible to discuss the unity of substance without discussing to some extent the difference in the form of law and gospel. For Calvin invariably makes such distinctions in the context of the same passage. Also, when Calvin discusses the common substance of the law and gospel, another topic frequently enters the picture: the experience of the fathers (i.e., the Old Testament believers) with Christ and the gospel.

It was noted above that the covenant made with the Old Testament "fathers" or patriarchs has the same substance and reality as that made with believers in the New Testament era. This key statement in the Institutes, (II.10.2) distinguishes Calvin from opponents on two sides: the Roman theologians on the one hand, and the Anabaptists on the other. Calvin, however, was no innovator in this respect, for Zwingli, Bucer, Melanchthon, and Bullinger had made similar distinctions prior to this time. ${ }^{81}$

For Calvin, the issue at stake is not only the unity of revelation but the unity of God himself. In those places where the law is opposed to the gospel, Calvin readily recognizes the antithesis, but at the same time he is quick to warn his readers that it would be erroneous to conclude that God is "unlike" or "inconsistent" 82 with himself. ${ }^{83}$

When we learn that the doctrine of the gospel 'came forth out of Zion' (Isa 2:3), we conclude from this that it is not new, or a recent innovation, but that it is the eternal truth of God of which a testimony had been given in all ages before it was brought to light. We also gather that it was necessary that all of the ancient ceremonies should be abolished and that a new form of instruction (nova docendi forma) should be introduced, although the substance of the doctrine (doctrinae substantia) continued to be the same. For the law formerly proceeded out of Mount Sinai (Ex 19:1), but it now proceeded 'out of Zion,' and therefore it took on a new form.

Two things, therefore, must be observed: First, that the doctrine of God is the same and always agrees with itself (et sui perpetuo similem); that no one may accuse God of changeableness (variationis) as if he were inconsistent. Although the law of the Lord is the same as always, yet it came out of Zion with new garments (veste). Second, when the ceremonies and shadows had been abolished, Christ was revealed in whom their reality was perceived. ${ }^{84}$

In this one quotation it becomes apparent what Calvin means by both the unity and diversity of the covenants. For him there is essentially only one covenant, the covenant of grace, which unites both Testaments. Here Calvin stands on firm ground, for the one covenant promise - "I will be your God and you shall be my people" - is repeated throughout Scripture. ${ }^{85}$

However, Jeremiah and Ezekiel speak of a "new covenant," and in Hebrews 8:6-13 we read that this new covenant, which is ratified by the blood of Christ, makes the "old covenant" obsolete. Calvin still insists that the so-called "new covenant" is not contrary to the first covenant. To draw 
such a conclusion would imply that God is not true to himself and is somehow inconsistent. "For he who once made a covenant with his chosen people has not changed his purpose as though he had forgotten his faithfulness." 86

What is "new" about the new covenant only refers to its form. The covenants made with Abraham, Moses, and David, and the new covenant promised by Jeremiah and Ezekiel, are all united by the one promise which finds its culmination and fulfilment in Christ. He is the fundamentum, anima, spiritus, perfectio, scopus, and finis of the law. ${ }^{87}$

Since Christ is the substance of the law, and thereby also of the two Testaments, they are inseparable and interdependent. The gospel does not supplant or supersede the law but rather confirms it and gives substance to the shadows. Consequently, "where the whole law is concerned, the gospel differs from it only in clarity of manifestation." 88

\section{Distinction in form}

The distinction between law and gospel - between the old and new covenants, as we saw earlier - consists principally in the mode of dispensation or manner of instruction. Calvin treats this subject in Book II, chapter 11 of the Institutes, although he had already dealt with this matter provisionally in chapter 9 . The title of this chapter indicates what the principal distinction is: "Christ, although he was known to the Jews under the law, was at length clearly revealed only in the gospel."

The tota lex is still the object of inquiry. In this context, the difference between the covenants is only relative, a matter of more or less; the substance is the same. Only the form or manner of God's self-revelation and our understanding and experience of it varies.

In view of all this, it might seem that Calvin has so moderated or smoothed out the differences between the Testaments, or the law broadly conceived, and the gospel, that the distinctions are not really significant. Before dealing directly with that objection, we should examine the five differences or distinctions which Calvin lists in chapter eleven.

1. The Jews were given the hope of immortality under the figure of earthly blessings, but now this inferior method has been suspended.

4. Truth was exhibited by types in the Old Testament, but is now openly revealed in the New, as we see in the Epistle to the Hebrews. This was due to the fact that the Jews were in a state of tutelage, except for the patriarchs who were in advance of their time.

5. The old covenant has the character of the letter, the new, of the Spirit; the old lacks the Spirit whereas the new is engrave on the heart (Jer 31:31ff.). The old is deadly because it includes the curse, the new is an instrument of life. The old is a shadow which must pass away; the new will stand forever.

6. The old covenant produces fear and trembling, except for the promises in it which properly belong to the new (so Augustine), whereas the new produces freedom and joy.

7. The revelation of the Old Testament was confined to the Jewish nation. In the New Testament the Gentiles are also invited to share in its blessings. ${ }^{89}$

A careful reading of these five differences shows that the third and fourth differences are not of the same character as one, two, and five. These three are of a less radical, more "evolutionary" type of difference whereas three and four come close to representing an antithesis between law and gospel. That is, the difference between the letter and the spirit, works and faith, bondage and freedom, are far greater than the movement from a more limited and obscure revelation to that which is clearer, fuller, and more universal. As Calvin himself points out, "Where the whole law (tota lex) is concerned, the gospel differs from it only in clarity of manifestation." 90

When one speaks of an "antithesis," as in the next section, a much sharper contrast or 
break is implied. However, even in this case the break or antithesis is never absolute because even the law (although not the nuda lex) is adventitiously invested with certain qualities of the gospel. This qualification is crucial for understanding Calvin's view of law and gospel and will be illustrated later.

\section{Antithesis between letter and Spirit}

Now we come to that aspect of the law which most Protestants take for the whole. This law, the law opposed to the gospel, is the law separated from Christ and the Holy Spirit. This is the bare law (nuda lex), the accusing law that troubles the conscience, the law in itself (per se) and as such which is isolated from the covenant and the promises. This law requires perfection, and where that is lacking, it curses, condemns, and kills. Over against the gospel, when each is taken in its narrower and peculiar sense, this law demands what only the gospel can give.

Does Calvin recognize such a law? Or is this only a minor motif in Calvin's theology, grudgingly conceded because of the strong Pauline evidence in favour of such a view? Is J. S. Whale correct when he affirms that "the gospel as it appears in Paul and John" is found "in clearer and brighter form in Luther than in Calvin"? 91

The best way to answer such questions is to examine Calvin's exegesis of a few key Johannine and Pauline texts. The first is John 1:17: "The law was given through Moses; grace and truth came through Jesus Christ." On the one hand, Calvin notes that "Moses' contribution was extremely scanty compared to the grace of Christ." This sounds like the comparisons we saw in the last section; it is simply a matter of more or less. But Calvin does not stop here. He proceeds to point out,

But we must notice the antithesis in his contrasting of the law to grace and truth; for he means that the law lacked both of these... Here we are dealing with ...the validity of the law in itself (per se) and apart from Christ. The evangelist denies that anything substantial is to be found in it until we come to Christ. Moreover, the truth consists in our obtaining through Christ the grace which the law could not give. ${ }^{92}$

A key Pauline text in this regard is Romans 4:15: "For the law brings wrath, but where there is no law there is no transgression." This is a very negative text, one where Calvin might be tempted to soften its sharpness. But he states unequivocally that

Since the law generates nothing but vengeance, it cannot bring grace. The law would, it is true, point out the way of life to men of virtue and integrity, but since it orders the sinful and corrupt to do their duty without supplying them with the power to do it, it brings them in their guilt to the judgment seat of God. ${ }^{93}$

In any discussion of Paul's view of the law two other texts of a similar nature are always brought forward: Romans 5:20 and Galatians 3:19. The former reads, "The law came in to increase the trespass..." Calvin begins his comments by making a characteristic distinction: Paul, here, he maintains, "is not describing the whole office and use of the law, but is dealing only with the one part which served his present purpose." 94

This qualification is crucial to an understanding of Calvin's view of the law: that when Paul speaks in this way of the law, he is not referring to the original meaning of Torah, the revelation of God's will for his people. Rather, he is limiting himself to only one aspect and function of the law. Another example of this qualification is seen in his commentary on Romans 7:2-3. Here, too, Calvin cautions, the apostle "refers only to that part of the law which is peculiar to the ministry of Moses." 95

The other text which seems to indicate an exclusively negative and secondary role for the law is Galatians 3:19: "Why then the law? It was added because of transgressions." Calvin again begins with characteristic cautions and qualifications. 
The law has many uses, but Paul confines himself to one which serves his present purpose. He did not intend to inquire how many ways the law is of advantage to men. It is necessary to put readers on their guard on this point; for I have found that many make the mistake of acknowledging no other use of the law than what is expressed here. Paul himself elsewhere speaks of the precepts of the law as profitable for doctrine and exhortation (2 Tim 3:16). Therefore this definition of the use of law is not complete and those who acknowledge nothing else in the law are wrong ${ }^{96}$ [emphasis mine].

The closing warning might be viewed as a criticism of Luther or some of his followers. However, a careful comparison of Luther's and Calvin's exegesis of key law-gospel passages in Galatians shows that the two reformers are in fundamental agreement on this issue. ${ }^{97}$

In Calvin's commentary on Galatians 2:19 one would think that this was Luther, not the Genevan reformer. The text goes: "For I through the law died to the law, that I might live to the law." Calvin comments:

We must not ascribe to Christ what is properly the task of the law. It was not necessary that Christ should annihilate the righteousness of the law, for the law slays its own disciples... It is the law which forces us to die to itself; for by threatening our destruction it leaves us nothing but despair and thus drives us away from trusting in it. ${ }^{98}$

It is necessary to examine Calvin's exegesis of one more passage, for here, more than anywhere else, the distinctive nuances of Calvin's understanding of the law are clearly delineated. The passage is 2 Corinthians 3:6-7: "For the letter [written code, RSV] kills, but the Spirit gives life." Calvin concludes that "letter" or "written code" (gramma) here refers to the old covenant whereas "Spirit" refers to the gospel. "By the word 'letter' Paul means preaching which is external and does not reach the heart; by 'Spirit' he means teaching which is alive, which works mightily in the souls of men by the grace of the Spirit." 99

Calvin sharpens the antithesis as he takes up the description of the law as a "ministry (or dispensation) of death" in verse 7. After analyzing various aspects of the comparison, he draws up a summary.

Let us now examine briefly the characteristics of the law and the gospel. But let us remember that the point at issue is neither the whole of the teaching we find in the law and the prophets, nor the experience of the fathers under the Old Testament but rather the peculiar function of the ministry of Moses. The law was engraved on stones and thus it was literal teaching. This defect of the law had to be corrected by the gospel, since the law could not but be breakable, having been consigned to tablets of stone. The gospel, therefore, is a holy and inviolable covenant because under God it was promulgated by the Spirit. It follows that the law is a ministration of condemnation and death, for when men are taught of their duty and are told that anyone who does not satisfy God's justice is cursed, they are guilty and found guilty of sin and death. Therefore, they receive nothing from the law but condemnation, for in the law God demands his due (exigit quod sibi debetur), but does not confer the power to perform it. The gospel, on the other hand, by which we are regenerated and reconciled to God through the free forgiveness of sins, is the ministration of righteousness and consequently of life itself. ${ }^{100}$

The real problem, however, is not that of demonstrating that Calvin takes the accusing, condemning function of the law seriously. Far more difficult is the matter of showing how he integrates this concept of the law with his understanding of the law as a whole. He frequently reconciles the apparent contradiction between the views of David (as in Psalm 119) and Paul concerning the law by suggesting that David is speaking of the whole law whereas Paul is speaking of the law in a limited sense.

Thus, when David praises the law, he is thinking not only of precepts and commandments 
but also of the promises of salvation as well. He rejoices in the law of the covenant, God's gift to Israel. Paul, however, is dealing with people who perverted and abused the law. They saw it as a means toward achieving righteousness rather than as a gift to a people already redeemed. They separated it from the grace and Spirit of Christ and hence experienced the law as sheer demand and therefore as deadly. ${ }^{101}$

However, with this explanation we still have not come to the crux of the matter. It is not just a question of the misunderstanding and perversion of the law by the Judaizers (so Barth). Nor is it only a question of the narrower and broader concepts of the law. There is something intrinsic in the law which distinguishes it from the gospel. The antithesis lies in the peculiar office, function, and ministry of the law. When the law is separated from the promises and the gospel, when it is viewed according to its peculiar properties in contrast to those of the gospel, the antithesis is radical and profound.

The explanation lies in the two "offices" (munera) of Moses, as Calvin understands them. One was general (in universum), "to teach the people the true role of piety." In this sense he was a minister of the whole law and preached repentance and faith. In fact, he proclaimed the promises of free grace and was thus a preacher of the gospel (evangelii praeconem)! 102

However, Moses also had another "office," which unlike his general office, he did not have in common with Christ.

This office was particularly imposed upon him, to demand perfect righteousness of the people and to promise them a reward, as if by compact, upon no other condition than that they should fulfil whatever was enjoined upon them, but also to threaten and declare judgment against them if they ever fell from the way... Therefore, it is important to distinguish between the general doctrine (generalem doctrinam) which was delivered by

Moses and the special commission (mandatum) which he received. ${ }^{103}$

When this distinction is understood, it is possible to see how Paul can speak on the one hand of the law as holy and good and on the other as the law of sin and death. The apostle, because of the situation in which he found himself, often pointed to that which was peculiar to Moses and distinct from Christ, even though they are in agreement as far as the substance of their doctrine is concerned. ${ }^{104}$ However, when Paul thus refers to that office of the law which was peculiar (propria) to the ministry of Moses, he is not referring to the ten commandments, "For the will of God must stand the same forever." ${ }^{105}$

\section{CONCLUSION}

For Calvin, therefore, the order may be put this way: Law of creation (natural law) - revealed law (the law of Moses) - the gospel - the gracious law (third use) as a norm and guide for believers. ${ }^{106}$ The same outline would follow for Luther except that the third or positive use of the law plays a minor role in his thinking. On the surface Barth would seem to have more affinity with Calvin because of their more positive evaluation of the law as a whole, but the differences are significant because of Barth's rejection of any notion of the antithesis of law and gospel and his subsuming the law in all its functions under God's grace.

What Luther said long ago in regard to this question still applies: "Whoever knows well how to distinguish the gospel from the law should give thanks to God and know that he is a real theologian."107

\section{KEY WORDS}

Karl Barth

Martin Luther 
John Calvin

law and gospel

letter and Spirit

(Endnotes)

1.1 Albertus C. Van Raalte, Professor of Systematic Theology, Western Theological Seminary, Holland, Michigan. This lecture was presented in the week of 11-15 July 2011 at Stellenbosch as visiting professor in the Discipline Group of Systematic Theology and Ecclesiology, Faculty of Theology, Stellenbosch University".

2 Cited in Donald K. McKim, editor, How Karl Barth Changed My Mind (Grand Rapids: Eerdmans, 1986), ix.

3 An English translation by A. M. Hall is included in the book Community, State, and Church. Three Essays by Karl Barth, with an Introduction by Will Herberg (Garden City, N.Y.: Doubleday Anchor Books, 1960). Another translation by J. S. McNab is found in a British edition entitled God, Grace and Gospel (Edinburgh: Oliver \& Boyd, Scottish Journal of Theology Occasional Papers, No. 8, 1959).

4 Will Herberg, ibid., 9.

5 The sharpest responses have been by the Swedish theologian Gustaf Wingren and German Lutheran theologians such as Werner Elert, Paul Althaus, and Gerhard Ebeling. Some of these writers will be cited later. There have been other German Lutheran theologians, however, who have been more sympathetic to Barth's approach, viz., Helmut Gollwitzer and Eberhard Jüngel.

6 See, for example, Colin Brown, Karl Barth and the Christian Message (London: Tyndale Press, 1967); and Herbert Hartwell, The Theology of Karl Barth (London: Duckworth, 1964). Another standard—and highly regarded - analysis of Barth's theology by the Swiss Roman Catholic theologian, Hans Urs von Balthasar, doesn't deal with the subject. See his The Theology of Karl Barth (San Francisco: Ignatius, 1992). The same is true of the two outstanding studies of Barth's theology by the eminent American interpreter, George Hunsinger: How to Read Karl Barth. The Shape of His Theology (New York: Oxford U. Press, 1991); and Disruptive Grace. Studies in the Theology of Karl Barth (Grand Rapids: Eerdmans, 2000). This lacuna is strange in view of the significant role the theme of gospel and law plays in Barth's theology.

7 Hendrikus Berkhof, Crisis der Midden Orthodoxie (Nijkerk: G. F. Callenbach, 1953); and G. C. Berkouwer, The Triumph of Grace in the Theology of Karl Barth (Grand Rapids: Eerdmans, 1956).

8 One exception are two lengthy essays by a graduate student at Yale Divinity School, Jesse Couenhoven: "Grace as Pardon and Power: Pictures of the Christian Life in Luther, Calvin and Barth" in Journal of Religious Ethics 28.1 (Spring 2000); and "Law and Gospel, or the Law of Gospel? Barth's Political Theology Compared with Luther and Calvin," in Journal of Religious Ethics, 30.2 (Summer 2002). The most thorough discussion of this issue is by an American Lutheran theologian, Gerhard O. Forde, but it is already thirty-five years old: The Law-Gospel Debate. An Interpretation of Its Historical Development (Minneapolis: Augsburg, 1969). Forde finds the genesis of the law-gospel debate not in Barth but in the theology of the nineteenth century theologian J. C. K. Hoffmann. In Part Two he takes up the theologies of Harnack and Ritschl under the caption "Wrath Versus Love." Only in Part Three does he deal with Karl Barth and the response of four Lutheran theologians.

9 There are also references to law and gospel in Barth's Credo, a discussion of the Apostles' Creed (London: Hodder \& Stoughton, 1936/1964); and Dogmatics in Outline (London: SCM Press, 1949/1957).

10 Gospel and Law, 71.

$11 \mathrm{Ibid} ., 71-2$. Barth is fond of using this sort of imagery in describing the relationship of the law to the gospel. Cf. page 80 in Gospel and Law. In the Church Dogmatics he says that "Jesus Christ himself . . is always clothed in the law, hidden in a manger and the swaddling clothes of the Commandments ..." (The Doctrine of God II, 2. Edinburgh: T \& T Clark, 1957), 563. Again in the Doctrine of Reconciliation, Church Dogmatics IV, 3 Barth writes in a similar fashion. The gospel, he says, "has also the form of the true law of God, the promise of the grace of God containing his no less gracious claim, as the ark of the Old Testament covenant contained the tables of the decalogue" (Edinburgh: T \& T Clark, 1961), 367. In short, "It is the gospel which contains and encloses the law as the ark of the covenant encloses the tables 
of Sinai," CD.II, 2, 511.

12 Ibid., 72.

13 Ibid., 76-7.

14 Gospel and Law, 80 (page 10 in the British version), CD. II, 2, 511. In the midst of his most important discussion of this issue in the Church Dogmatics (IV.3, 369ff.), Barth reverses this formula and says that "the Gospel ... has also the form of the true law of God. ..."

15 Ibid.

16 G. Ebeling, Word and Faith (Philadelphia: Fortress Press, 1963), 267. (It is significant that Eberhard Jüngel, a much more sympathetic interpreter of Barth, also speaks of "the unfortunate logic" of the statement that "the law is the necessary form of the gospel," op. cit., 116).

17 Hartwell, op. cit., 158.

18 Gospel and Law, 81.

19 Gospel and Law, 77, 81, 95. CD.II, 244, 639. "Jesus Christ, as true God and true man, is the divine law to which we are subject. ... He, as true God and true man, is also the fulfillment of the law." The Knowledge of God and the Service of God (London: Hodder and Stoughton, 1938/1960), 141.

20 Gospel and Law, 72. "The one Word of God, which is the revelation and work of his grace, is also law," CD.II, 2, 511.

21 Ibid., 77.

22 Ibid., 81. Jesus Christ "has done what he has done, in our place and for our sake. So now we have done - in him - what he has done, and so this divine acknowledgement of his obedience benefits us directly," Barth, The Knowledge of God and the Service of God, 142.

23 CD.II, 2, 511. "That the nature of the command of God is spiritual means that it does not confront us as an ideal, whether that of an obligation or of a permission, or that of a combination of the two, but as the reality fulfilled in Jesus Christ. This person is not only the ground and content but also the form of the divine claim," CD.II, 2, 606.

24 Barth, The Knowledge of God and the Service of God, 130. Jesus Christ "is the electing God and elected man in One. But he is also the sanctifying God and the sanctified man in One," CD.II, 2, 538-9.

25 Colin Brown, Karl Barth and the Christian Message, 128.

26 Gospel and Law, 89, 91.

27 Ibid., 94.

28 Berkhof, Crisis der Midden-orthodoxie, 29, as cited in Berkouwer, The Triumph of Grace in the Theology of Karl Barth, 319.

29 Berkouwer, op. cit., 319.

30 Otto Weber, Foundations of Dogmatics, Vol. 2 (Grand Rapids: Eerdmans, 1983 - original German 1962), 379. The biblical theologian Brevard Childs suggests that Barth's 'fusion' of law and gospel can lead to confusion concerning the role of the church in the political realm. "What happens," he asks, "when law and gospel are simply fused, when the church seems fully confident that it knows what God wants and seeks to implement his will by human intervention? Is it not equally a threat to the gospel when it becomes indistinguishable from the law and vice versa? . . It is ironical that Barth's theology which sought to return the church to the proclamation of the gospel in opposition to cultural Christianity should now be largely identified with a form of political activism espoused by the left." Biblical Theology of the Old and New Testaments (Minneapolis: Fortress Press, 1993), 560-1.

31 One is Helmut Gollwitzer; Eberhard Jüngel is another. Gerhard Forde in his book The Law-Gospel Debate summarizes the positions of the chief protagonists. See note 4 in this regard. Forde is a Lutheran and is not in agreement with Barth's approach, but at the same time is critical of the "confused and inconsistent" attacks by some Lutheran theologians, e.g., Helmut Thielicke and Gustaf Wingren. See chapter 9, "The Reply to Barth."

32 So George Hunsinger. "Often regarded as supporting Barth from Luther, the law/gospel versus the gospel/law contrast may actually have more to do with what separated Barth from Lutheranism, "Disruptive Grace. Studies in the Theology of Karl Barth (Grand Rapids: Eerdmans, 2000), 304, n. 41. 
33 So the Oxford University theologian/ethicist, Nigel Biggar is his chapter on "Barth's Trinitarian Ethic" in The Cambridge Companion to Karl Barth, edited by John Webster (Cambridge, England: Cambridge U. Press, 2000), 225-6, no. 4. Elsewhere, however, Biggar points out that "unlike Luther, Barth does not correlate the Old Testament to the law, and the New to the gospel. The dialectic of law and gospel is operative in both Testaments, but in the New the priority of gospel to law is unequivocally established," The Hastening That Waits (Oxford: Clarendon Press, 1993), 121.

34 See the Lutheran quarterly, dialog. A Journal of Theology 39:3 (Fall 2000), whose theme is "LawGospel Preaching."

35 Sasse, Here We Stand (Minneapolis: Augsburg Publishing House, 1938/1946), 163. Werner Elert is equally certain that Barth's position is basically that of Calvin. He maintains that Barth's expression that "the law is only a form of the gospel coincides exactly with the view of Calvin," Law and Gospel (Philadelphia: Fortress Facet Books, 1967), 8.

36 Church Dogmatics III, 1. The Doctrine of Creation (Edinburgh: T \& T Clark, 1958), 604.

37 CD.IV, 3, 369. "If we have not heard the gospel, we shall never hear the law. The law that we think we hear without the gospel is certainly not God's law. We shall then certainly not be able to fulfill God's law, not because it is too hard and grievous for us, but because we do not yet know it. If we know it, we should cling to Christ in whom it is fulfilled. . ., " Credo, 58. Jesus Christ "is the law or norm of God confronted and measured by which man is shown up as a transgressor, and specifically as a deceiver and liar,"

CD.IV, 3, 371 .

38 Gospel and Law, 84.

39 Translation found in Ecumenical Creeds and Reformed Confessions (Grand Rapids: CRC Publications, 1988).

40 Jüngel, Karl Barth, 120.

41 He cites W. Elert, P. Althaus, E. Sommerlath, H. Thielicke, W. Joest, and G. Wingren.

42 CD.IV, 3, 370.

43 Ibid.

44 Luther, Lectures on Galatians 1535, chapters 1-4, translated by Jaroslav Pelikan (St. Louis: Concordia, 1963), 308.

45 Ibid., 309.

46 Ibid.

47 Calvin, Institutes of the Christian Religion, edited by John T. McNeill and translated by Ford Lewis Battles (Philadelphia: Westminster, 1960), II.7.12.

48 Luther, Galatians, 309. Citing Jeremiah 23:29, Luther uses similar language to describe this use of the law: The proper and absolute use of the law is to terrify with lightning (as on Mt. Sinai), thunder, and the blare of the trumpet, with a thunderbolt to burn and crush that brute which is called the presumption of righteousness," ibid., 310 (emphasis mine). Later he calls it "the true and proper use of the law," 312; "the best and most perfect use of the law," ibid., 316 (emphasis mine).

Since Calvin uses almost identical language to describe the third use of the law, Werner Elert claims that Calvin here "is waging a polemic against Luther with deliberate sharpness," Zwischen Gnade und Ungnade (München: Evangelischer Pressverband, 1948), 166 (translation mine). This is highly unlikely, for there is no evidence that Calvin and Luther had any significant differences about this question. The conflict between Lutheran and Reformed theologians about law and gospel is a later development.

49 Ibid., 315.

50 Holl, Gesammelte Aufsätze zur Kirchengeschichte, Vol. I (Tübingen: Mohr, 1932), 178. Some of the following material is taken from my book, Calvin's Concept of the Law (Allison Park, PA.: Pickwick Publications, 1992), $102 \mathrm{ff}$.

51 Heintze, Luthers Predigt von Gesetz und Evangelium (München: Chr. Kaiser, 1958), 110f. Whereas Calvin placed great emphasis on the evangelical character of the preface to the Decalogue ("I am the Lord your God, who brought you out of the land of Egypt ..."), Luther virtually ignores it and makes much of the first commandment of the decalog. He calls it "the fountainhead of all the commandments" 
(fons omnium praeceptorum), Sermon on Deut. 1 (WA 28, 510), quoted in Heintze, ibid., 111. In his exposition of the ten commandments in his Large Catechism Luther writes: "This word, 'you shall have no other gods,' means simply, 'You shall fear, love, and trust me as your one true God.' Wherever a man's heart has such an attitude toward God, he has fulfilled this commandment and all the others," The Book of Concord. The Confessions of the Evangelical Lutheran Church, translated and edited by Theodore G. Tappert (Philadelphia: Fortress, 1959), 409.

52 The Book of Concord, 361, 407. At the very end of his conclusion he writes again enthusiastically,

"From all this it is obvious once again how highly these ten commandments are to be exalted and extolled above all orders, commands, and works which are taught and practiced apart from them. .. . Therefore we should prize and value them above all other teachings as the greatest treasure God has given us," ibid., 410-11.

53 Article II, "The Law,” in Book of Concord, 303.

54 Book of Concord, 304.

55 Mc Donough, The Law and the Gospel in Luther. A Study of Martin Luther's Confessional Writings (London: Oxford U. Press, 1963), 144.

56 See, for example, Luther's "Treatise on Good Works" in Luther's Works, Vol. 44, edited by James Atkinson (Philadelphia: Fortress, 1966), 23ff.

57 Mc Donough, op. cit., 87.

58 Thielicke, Theological Ethics. Foundations, Vol. 1 (Philadelphia: Fortress, 1966), 133-4. The Luther quotation is from WA 39, 485.

59 Ibid., 55. Paul Althaus, another German Lutheran, would appear to concur with Thielicke's judgment. Summarizing Luther's position regarding God's law and the Christian life he writes: "When the sinner has been justified, the law takes on new meaning for him: Christ has fulfilled the law for us. Thereby we are relieved of the terrible burden that there can be no salvation for us unless we completely fulfill the law. This one barrier to recognizing the law as an expression of God's eternal goodwill is now set aside. Now man is able to love God's law with his whole heart just as he loves God himself-for the content of the law is the form and expression of the nature of God," The Ethics of Martin Luther (Philadelphia: Fortress, 1972/86), 11-12.

60 There is no significant difference between the two expressions as used by the reformers: lex naturae and lex naturalis.

61 Barth is convinced that the idea of natural law is more stoic than biblical. He gets around the standard interpretation of Romans 2:14-15 by maintaining that the Gentiles in this passage are Christian Gentiles, not pagan Gentiles. The phrase "the law written on their hearts" is then an allusion to Jeremiah 31:33. Barth had not yet come to the conclusion in his commentary on Romans, but it is found in his Church Dogmatics and in his Shorter Commentary on Romans. One of the few commentators who defends this view is C. E. B. Cranfield in Romans. A Shorter Commentary (Grand Rapids: Eerdmans, 1985), 50-2.

\section{Institutes II.8.1.}

63 Ibid.

64 "We observe that there exist in all men's minds universal impressions of a certain civic honesty and order," Inst. II.2.13.

65 Institutes II.2.22. Conscience plays the same role. See Inst. I.5.15. For a more thorough discussion of Calvin's view of natural law see my Calvin's Concept of the Law, chapter II.

66 “Treatise on Secular Authority," in Martin Luther. Selections from his Writings, edited by John Dillenberger (Garden City, N.Y.: Doubleday Anchor Books, 1961), 401. Paul Althaus, drawing on a number of sources, concludes: For Luther, "The natural law is thus nothing else than the commandment of the law of love .... Christ and the natural law teach one and the same thing ... . Thus Luther considers that all the rules of the Sermon on the Mount ... are part of natural law," The Ethics of Martin Luther, 29.

67 WA XLII, 374, 11ff., cited in Philip S. Watson, Let God be God. An Interpretation of the Theology of Martin Luther (London: Epworth Press, 1947/54), 82. Calvin also has a high regard for pagan writers, especially Plato and Cicero. However, he does not ascribe their virtues to a knowledge of the law of nature but rather to the "general grace of God" (generalem Dei gratiam) and the work of the Holy Spirit. 
See Institutes II.2.2-3, 15 and 17.

68 W.A. XXXIX, 1, 454, 4, cited in Watson, op. cit., 98, n. 44.

69 WA XVI, 447, 26ff., cited in Watson, 99, n. 52.

70 “How Christians Should Regard Moses," in Martin Luther's Basic Theological Writings, edited by

Timothy Lull (Minneapolis: Fortress, 1989), 139-140.

71 Ibid., 145.

72 Ibid., 140, $2,7$.

73 Timothy Lull, the editor of the large volume of selections, including the sermon on "How Christians

Should Regard Moses, " writes in his introduction, "The deepest obstacle to hearing Luther in today's theological discussions is that his theology is so rich, complex, and dialectical that he seems unreliable both as an opponent and as an ally. There is always with Luther the element of surprise, "ibid., 2.

74 Seeberg, Lehrbuch der Dogmengeschichte IV, 2 (Basel: Benno Schwabe, 1960), 566, translation mine.

75 Ibid., 565, 613, 631.

76 Von Schubert, Kirchengeschichte, Elfte Auflage (Tubingen: J. C. B. Mohr, 1950), 207, translation mine. Further illustrations of such caricatures can be found in my Calvin's Concept of the Law on which I shall be drawing heavily in this section as well as a chapter entitled "Law and Gospel or Gospel and Law?

Calvin's Understanding of the Relationship" in the book Calviniana. Ideas and Influences of Jean Calvin, edited by Robert V. Schnucker (Kirksville, MO: Sixteenth Century Journal Publications, 1988). A far more detailed account of Calvin's position will be found in these two sources.

77 Kraeling, The Old Testament Since the Reformation (London: Lutterworth, 1955), 31.

78 Calvin, Commentary Exodus 19:1, Harmony of the Last Four Books of Moses I, 314. The following paragraphs are taken from my essay, "Law and Gospel or Gospel and Law?", 17ff.

79 Institutes II.7.2.

80 See Calvin's Comm. Deut. 30:11; Psalm 19:7-8; Romans 10:5; and 2 Corinthians 3:6.

81 See Gottlieb Schrenk, Gottesreich und Bund im alteren Protestantismus (Damstadt: Wissenschaftliche

Buchgesellschaft, 1967 [reprint of 1923 ed.]).

82 Comm. Gal. 3:2; Sermons on Gal. 2:15-16; and Gal. 3:11-14.

83 Comm. Hab. 2:4; Heb. 1:1-2.

84 Comm. Isaiah 2:3.

85 See Lev. 26:12; Jer. 31:31; 2Cor. 6:16; Heb. 8:10.

86 Comm. Jer. $31: 31$.

87 Comm. 2 Cor. 3:6-7; Comm. Jer. 31:31-2; Comm. Matt. 17:3; Comm. Rom. 10:45.

88 Institutes II.9.4.

89 This is a summary of the main points of the Institutes II.11.

90 Institutes II.9.4.

91 J. S. Whale, The Protestant Tradition (Cambridge: Cambridge U. Press, 1955), 164.

92 Comm. John 1:17. Cf. Inst. II.7.16.

93 Comm. Rom. 4:15.

94 Comm. Rom. 5:20.

95 Comm. Rom. 7:2-3.

96 Comm. Gal. 3:19.

97 I demonstrate this in an essay, "Luther and Calvin on Law and Gospel in Their Galatians

Commentaries," in Reformed Review 37/2 (Winter 1984).

98 Comm. Gal. 2:19.

99 Comm. 2 Cor. 3:6.

100 Comm. 2 Cor. 3:7.

101 Cf. Comm. Ps. 19:7-8; Comm. Acts 7:38; Comm. 2 Cor. 3:14-17. 
102 Comm. Rom. 10:5.

103 Comm. Ex. 19:1.

104 "The End and Use of the Law," in Commentary on the Last Four Books of Moses, 3. Cf. Comm. 2 Cor. 3:6-10.

105 Comm. Rom. 7:2. Because of space limitations I must end here but in my essay on "Law and Gospel or Gospel and Law" I go on to point out that: (1) Another difference between law and gospel relates to sin and hence the negative aspect of the law is "accidental." (2) It is not the law, therefore, that is defective but the weakness of our flesh. (3) However, the curse of the law is not only accidental but also inseparable from its nature.

106 I question Couenhoven's conclusion that "in the third use of the law, Calvin reverses the order of law and gospel, putting gospel before the law." His rationale for this statement, however, contains some truth. "For those who trust in God's promises the law takes the form of a gift, even so it presents the task of the Christian life. Thus, Calvin begins to find the gospel in the law," "Grace as Pardon and Power," op. cit., 69. Actually this applies more to the way Calvin handles the original giving of the ten commandments on Mt. Sinai. He makes much of the Preface to the decalog, "I am the Lord your God . . " pointing out that the law is thus a gift to a people already redeemed and was not originally intended as a burden. See Institutes II.8.13-15.

107 Commentary on Galatians, 115. "Such a proper distinction between the function of the law and the gospel keeps all genuine theology in its correct use," ibid., 331. 